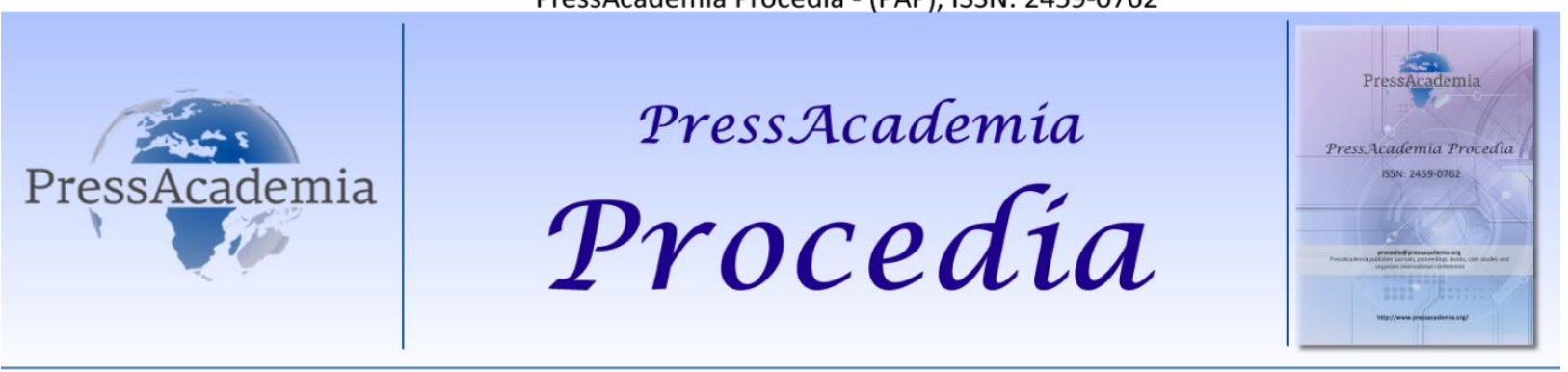

2nd World Conference on Technology, Innovation and Entrepreneurship, May 12-14, 2017, Istanbul, Turkey. Edited by Sefer Şener

\title{
INTEGRATION AND VOCATIONAL COURSE SUGGESTIONS FOR MIGRANTS
}

\section{DOI: 10.17261/Pressacademia.2017.557}

PAP-WCTIE-V.4-2017(49)-p.375-378

\section{Burcu Bektas ${ }^{1}$, Erdogan Kose ${ }^{2}$}

${ }^{1}$ Istanbul University, burcu.bektas@istanbul.edu.tr

${ }^{2}$ Istanbul University, erdogan.kose@istanbul.edu.tr

\begin{abstract}
When the terrorist activities across the world are considered, Turkey is also affected by the migration wave created by it. According to the official numbers, Turkey now hosts 3 million migrants whereas the unofficial numbers claim that this reaches to 5 million people. The new lives people establish in Turkey bring several integration problems such as loneliness, social isolation, alienation, regret or feeling invaluable. Therefore, it is essential that these people improve their language skills and develop skills in order to leave in harmony and peace with the local residents and to overcome the difficulties rising from cultural differences. To serve this aim, integration programmes and vocational courses can help people overcome the integration problem as well as help them gain a skill that could create job opportunities for them. Within the scope of this research, different courses that could be offered to migrants and their potential impacts on these people will be looked into.
\end{abstract}

Keywords: Integration and vocational courses, migration, education/training JEL Codes: G10; G32

\section{INTRODUCTION}

The movement of migration can be defined as the act of abandoning a permanent habitat of a population for personal reasons in order to live either permanently or temporarily in another place. (Doğanay, 1994). There are several reasons why people abandon the countries or cities they were born in. Some of the reasons for migration can be listed as; population problems, economic problems, deterioration in environmental conditions, inadequacy of educational conditions, political problems and wars. Among them, economic and political problems are the most significant reasons. Inequality in income distribution, economic reasons such as unemployment and poverty have shown that a large number of people are abandoning the countries/cities they live in. Political problems also play a role in forcing people to migrate. Natural phenomena such as environmental degradation, climate change, erosion, floods, earthquakes and volcanic eruptions are the most important reasons for people to migrate. (Kaştan, 2015). Migration can cause a variety of damages to the mental health of children and adolescents such as adjustment or adaptation problems. Köknel (1989) defines the adjustment as "the ability of the individual to have and maintain a balanced relationship between his / her self and the environment". (Köknel, 1989). Adaptation problems are also reflected in the education of children and adolescents, and these children experience various difficulties in the schools. Tufan defines the characteristics of a well-adjusted person as "being able to perceive the truth; to be in a comfortable relationship with the facts, to acknowledge oneself without worry, to be natural in behaviours, to have motivation for a positive start, to be flexible in behaviours, to have self-confidence, to have expectations about life and future". (Tufan, 1987). Therefore, it is necessary for the individual to adjust the environment $\mathrm{s} /$ he lives in. Overcoming the feeling of loneliness, social isolation, regret and feeling insignificant can contribute to the country with the achievement s/he will be doing.

Educational and economic development are inseparable. Training of citizens who can adapt quickly to the needs of the information age is one of the basic priorities of the civilized world. Training migrants as well as the citizens and sustaining their integration via education so that they can contribute to the society may be considered an important asset within the scope of life-long learning. The concept of Lifelong Learning takes place in the studies of many national and international institutions and organizations (such as UNESCO, ILO, OECD, EU). (Beycioğlu and Konan, 2008). European union defines the life-long learning as activities that aim to improve the individual's knowledge, skills, competences for personal, social or 
professional development throughout his / her life (European Commission, 2002). The idea that education encompasses the whole of life has existed for a long time (Lindeman, 1926; Yeaxlee, 1929). In recent years there has been an increase in interest in lifelong learning to organize it in a much better and professional way. The aim of the Lifelong Learning model is to ensure that both non-formal education and the formal education are carried out successfully. (Köse, 2016). Likewise, Ministry of National Education (MonE) states in the article 4-1.e of objectives and duties of Regulation on Non-formal Education Institutions document that MoNE "should hold training activities for migrants to help adapt to their new environment." This shows that MoNE attaches importance to training that could address integration of migrants. (Republic of Turkey Ministry of National Education, 2010). As for the citizens, the aim of the courses is to improve the cooperation between the university - industry and local governments and to find a solution to the problem of unemployment in our country. When looked from the perspective of migrants, the aim of the courses is to eradicate the integration problems, to contribute to the welfare of the country by raising qualified personnel and to teach history and cultural structure and the official language of the country.

\section{TRAINING WITHIN THE SCOPE OF INTEGRATION AND VOCATIONAL COURSE}

The number and accessibility of language courses offered for migrants at public education centres and in some nongovernmental organizations are limited. In addition to the language courses, hobby courses can help migrant spend nice time and some special courses that can be offered at universities can address the aspirations of young people who wish to pursue a higher education degree. These trainings are defined as "Integration and Vocational Courses" and they should be available to all migrants who are unemployed or who do not have a job regardless of their educational level. Courses should be organized in such a way that it can to respond to market demands in accordance with the changing needs of the world, as well as the scope of innovation and change.

\section{THE SOCIAL ASPECTS OF THE COURSES}

From the perspective of clinical psychology, migration includes many social factors and it is also a psychologically challenging process. From this point of view, psychology of migrants can be affected by pre-migration and post-migration factors. Pre-migration factors usually include the personality of the migrant, the way of migration, the country from which migrant come from or in which immigrant was exposed to torture. The post-migration factors are; grief related to migration, cultural shock, the differences between the expectations and reality in the host country, feeling of belonging in the host country, etc. (Republic of Turkey Ministry of Interior Directorate General of Migration Management, 2013). Within this context, courses will play a crucial role for migrants to overcome the language and culture problems and will be an important step in terms of addressing psychological and social aspects. Once the language and culture problems are addressed, adaptation will be much easier and the courses will help them overcome the unemployment problems as they will be equipped with necessary skills and knowledge for a job.

\section{INTEGRATION AND VOCATIONAL EDUCATION COURSES}

Vocational courses listed below can help migrants for integration and awareness:

1. Living in Turkey

- Political and Legal arrangement

- Political Participation and Parties

- Religious Communities

2. Living in Turkey

- $\quad$ Searching for a flat and moving

- Renting and Rent Law

- Buying a flat

3. Shopping and Consumer Protection

- Shopping and Consumer Protection

- Shopping hours

- Payment of Purchases

- Online shopping

4. Banks and Insurance

- Money and Bank

- Legal and Social Insurance

- Financial and Personal Insurances

5. Health and Measure

- Assistance for Diseases and Accidents 
- Preventive examinations and vaccinations

- Drug and Addiction Counselling

- Participation of disabled people in Daily life.

6. Learning Turkish

- Turkish for Profession

- Turkish for refugees

- Turkish for children and young people

7. Provision of Integration Processes in the Place of migrants

- Culture of welcoming

- Entertainment and sports options

- Strengthening Competencies

- Opportunities for women

8. Informing and Counselling

- Counselling for Adults

- Youth counselling

- Citizenship services

- Media communication

9. Education

- Early childhood education

- School system

- Vocational Training

- Higher Education

- Adult education

10. Job and Occupation

- Access to the labour market

- The Equivalency of degrees obtained from abroad

- Job hunting

- Special options for professional integration

> School/Vocational Education Transition

$>$ Establishing a business and working freelance

$>$ In-service training

- Business law

- Income and tax

11. Children and Family

- Childcare

- Pregnancy and Maternity Leave

- Parental Allowance and Parental leave

12. Association and Organisations

- Associations and Unions

- Immigration Organisations

13. Cultural Options

Migrants who have attended integration training need to work to improve their economic well-being once they have provided adaptation to the county and culture. The following vocational courses have been proposed in order to ensure that unemployed young people are trained as qualified workers and that they are able to make choices according to their job potentials in the areas and skills they are interested in

How to use a keyboard (F or Q)

General Information Technologies

Internet Programming

Computer Maintenance and Hardware

Computer Management

Graphic Design with Photoshop

Indesign - Graphic Design with Illustrator

Cleaning Services in Health Institutions

Worker Health and Work Safety in Health Institutions

Work Accidents and First Aid Training 


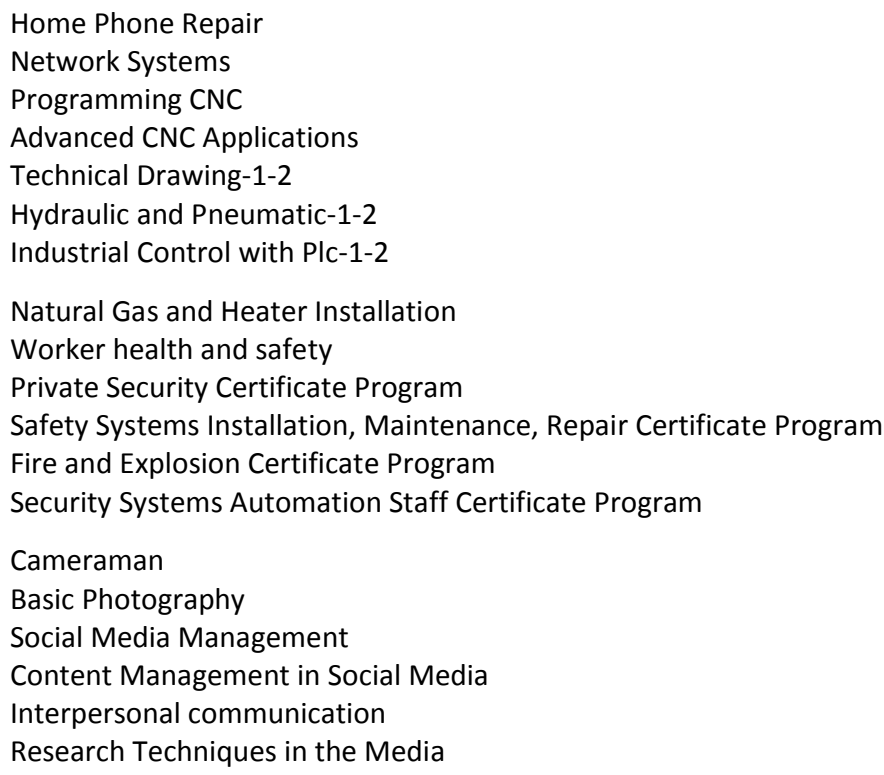

\section{CONCLUSION}

The aim of the proposed courses is to address the need for qualified labour force by providing integration and vocational training for migrants, thus seeking a solution to the problem of unemployment of the country and increasing the welfare of the country. The aim is to ease adaptation of migrants, to raise unemployed youth as qualified members of society and encourage them to work in the labour market of the region they are living in accordance with their skills and interests. Finally, the aim is to help people at all levels to adapt to innovation and change in today's world, and to ensure that they are lifelong learners within context of equal opportunities.

\section{REFERENCES}

Beycioğlu, K. ve Konan, N. 2008, "Lifelong Learning and Education Policies of The European Union", Electronic Journal of Social Sciences, V.7, I.24 pp.369-382.

Doğanay H. 1994, “Turkey's human geography”, Gazi Büro Publishing House, Ankara, pp.165.

European Commission, 2002, "European report on quality indicators of lifelong learning Fifteen quality indicators", European Commissıon report, Directorate-General for Educatıon and Culture, Brussels.

Kaştan Y. 2015, "Problems on Migration Process of Children Lived in Turkey", International Journal of Social and Educational Sciences, Volume 2, Issue 4.

Köknel Ö. 1989, "Individual and Social Violence”, Altın Kitaplar Publishing House, Istanbul, pp.9.

Köse E. 2016, “Continuous Learning Model in the Cooperation of University and Industry”, 2nd Educational Congree.

Lindeman E. 1926, "The Meaning of Adult Education",Newyork: New republıc inc.

Republic of Turkey Ministry of Interior Directorate General of Migration Management, 2013, "Migration management adaptation workshop", http://www.goc.gov.tr/files/_dokuman36.pdf, pp.30 (Access Date: 04.2017).

Republic of Turkey Ministry of National Education (MonE), 2010, Regulation on Non-formal Education Institutions, http://mevzuat.meb.gov.tr/html/yayg\%C4\%B1negi_1/27587_1.html (Access Date: 04.2017).

Tufan B. 1987, "Psycho-social situations of second generation immigrant working children returning to Turkey", Prime Ministry State Planning Organization (D.P.T.), Social Planning Department, Planning Department Publications, Ankara, pp.4.

Yeaxlee, B. A. 1929, “Lifelong Education”, London: Cassell. 